\section{UK plans to encourage physician scientists}

Faced with a growing difficulty in filling toplevel clinical research positions in its medical schools, the British government has been urged to help finance the creation of a new nationwide scheme of tenure-track 'clinical scientists', intended to make research careers more attractive to qualified physicians. The government is also being pressed to develop a new 'research training access scheme' that would provide around 50 posts annually for outstanding young doctors.

Both proposals were made in a report published last month by the Academy of Medical Sciences and were based on the conclusions of a working party chaired by John Saville, a professor of clinical science at the University of Edinburgh. The problem they seek to address was highlighted by a survey last year by the British Medical Association and the Council of Heads of Medical Schools, which assessed 17 medical schools and found that 74 of 401 clinical chairs were vacant, and that almost half of these had been empty for more than a year.

A number of reports in recent years have identified the difficulties faced by clinical researchers in medical schools, such as changes to career structures introduced within the National Health Service (NHS) in response to demands for greater costeffectiveness, and pressures on universities to produce high-quality research, as reflected in the research assessment exercise (Nature Med. 4, 990; 1998).

Saville's report, however, is the first to put forward concrete recommendations as to how this problem can be addressed. It proposes a set of changes that Saville hopes will provide a solid career structure for those keen to combine clinical and research responsibilities, while permitting sufficient flexibility to ensure the demands of both can be met. Its "key recommendation" is the immediate introduction of 50 'clinician scientist' posts per year to "nurture a cadre of research-led clinical academics in both specialists and generalist medicine for the equivalent of at least two years of protected postdoctoral research."

One important aspect of this scheme is that the posts would hold tenure-track status within the host medical schools. Another is that they would have sufficient built-in flexibility to allow occupants to move between medical schools. Some of the fellowships would be earmarked for research in disciplines-such as obstetrics and gynecology, or the surgical disciplines-which the report says are now in difficulty "because of a lack of academic critical mass."

The proposals have been welcome by both the Medical Research Council and the Wellcome Trust, both of which now provide funds for research positions at this level. Saville is confident that, at least initially, it would be possible to make up the full 50 posts by re-deploying existing university and health service funds. However, John Pattison, former Dean of Medicine at University College, London, and now head of the NHS research directorate, says that it will be several months before the division of the funds is decided.

David Dickson, London

\section{Italy creates neuroscience network}

Italy's research minister, Ortensio Zecchino, has announced the creation of a national neuroscience network to be supported by an annual fund of IL 40 billion (US\$ 20 million)-more than doubling public investment in neuroscience research. The country's five leading neuroscience centers are expected to make up the core of the network (see table), and a 29-member committee will meet for the first time on 4 May to begin selecting additional centers.

According to Vincenzo Sica, undersecretary of state for research, "neuroscience is a key part of a major move to raise general research spending from its current level of $1.2 \%$ GDP to $2.4 \%$ in the next triennium." Neuroscience research has been

\begin{tabular}{|c|c|c|c|c|}
\hline Center & $\begin{array}{l}\mathrm{N}^{\circ} \text { publications } \\
\text { (since 1995) }\end{array}$ & $\begin{array}{c}\text { Total } \\
\text { impact factor }\end{array}$ & $\begin{array}{l}\text { Citation Index } \\
\qquad|S|\end{array}$ & $\begin{array}{l}\text { Amount of funding } \\
\text { (since 1995) }\end{array}$ \\
\hline $\begin{array}{l}\text { Istituto Scientifico } \\
\text { San Raffaele } \\
\text { Milan }\end{array}$ & 532 & 1997 & 4677 & $\begin{array}{l}\text { IL } 20 \text { billion } \\
\text { (US } \$ 10 \text { billion) }\end{array}$ \\
\hline $\begin{array}{l}\text { Istituto Nazionale } \\
\text { Neurologico Carlo } \\
\text { Besta, Milan }\end{array}$ & 243 & 1202 & 2786 & IL 15 billion \\
\hline $\begin{array}{l}\text { University of Rome } \\
\text { "Tor Vergata" }\end{array}$ & 329 & 1312 & 2148 & IL 7.5 billion \\
\hline $\begin{array}{l}\text { Rita Levi- } \\
\text { Montalcini Center } \\
\text { for Brain Repair, } \\
\text { University of Turin }\end{array}$ & 229 & 1201 & 2145 & IL 9 billion \\
\hline $\begin{array}{l}\text { Centro per la } \\
\text { Neurofarmacologia } \\
\text { CNR - University of } \\
\text { Cagliari }\end{array}$ & 266 & 827 & 1985 & IL 6,5 billion \\
\hline
\end{tabular}

singled out as the first part of this program because of new advances in the field within the past decade.

Inclusion criteria for the network will be based on international ranking systems, such as the ISI citations, and the ability of a center to establish a more integrated approach of different disciplines. Jacopo Meldolesi, director of the neuroscience department at Istituto Scientifico San Raffaele, Milan, who sits on the committee, says, "The challenge now is to explore the frontiers between branches, such as molecular genetics and cell biology, that so far have developed almost independently." However, many scientists from smaller groups are concerned about the criteria for joining the network.

PierGiorgio Strata, head of the Rita Levi-Montalcini Center for Brain Repair, University of Turin, chairman of the committee and the most active proponent for the creation of the new network, insists that the smaller groups “...will be carefully considered as offering potential for strengthening Italy's neuroscience within the new network." The complete listing of groups within the network is expected to be announced at the end of June.

Martina Ballmaier, Milan 